\title{
Interference of First Language in Secondary School Students
}

\author{
Alia N. Abdullah, Melor Md. Yunus, Harwati Hashim, Siti Shakirah Binti Sayadi, Nursyuhada Alia \\ Binti Seman, Zainie Binti Ibrahim, Nur Alia Afifah Binti Zakaria
}

\begin{abstract}
First language (L1) interference is inevitable in second language (L2) acquisition. The research was carried out to investigate types of students writing approach that relates to first language interference among upper secondary students and the level of first language interference in L2 written essays among lower secondary students in Malaysia. The participants in this research were 50 students currently studying Form Four in a state-funded school, Akademi Menara Gading, Pahang. The data was collected using the Student L1 Interference Tendency Questionnaire [SLITQ], and analysis of students' essay writing samples. After triangulating the data, the result indicated that most students positive they have under-differentiation in their essay writing, and analysis of the student's written essays showed that there is less evidence of L1 interference. In conclusion, teachers and schools should acknowledge L1 interference in students' writing skill and promote a variety of writing strategies to support students existing writing skills.
\end{abstract}

Key Words: ESL, L1 interference, language transfer, writing skills, second language acquisition, writing strategies

\section{INTRODUCTION}

Writing presents a great deal of difficulty either in the first language or in a second language; English. Most scholars do agree that English writing in is among the utmost challenging skill [8][22][26][29]. Nunan [27] also has the same opinion that the skill is the most challenging task in language learning for ESL learners as they must write with coherence and fluency. Provided by the heavy demands in writing, it is a grueling process of discovering and organizing ideas to present meanings for ESL learners too. Hence, during writing, it is unescapable to make mistakes, especially for the writers who use it as a second language. However, Dulay, Burt and Krashen [9] suggest that the errors can be identified by analyzing the language systems of

Revised Manuscript Received on September 22, 2019

Alia N. Abdullah, Faculty of Education, Universiti Kebangsaan Malaysia, Bangi, Selangor, 43600, Malaysia.

Melor Md. Yunus, Faculty of Education, Universiti Kebangsaan Malaysia, Bangi, Selangor, 43600, Malaysia.

Harwati Hashim, Faculty of Education, Universiti Kebangsaan Malaysia, Bangi, Selangor, 43600, Malaysia.

Siti Shakirah Binti Sayadi, Akademi Menara Gading, Balok, Pahang, 26100, Malaysia.

Nursyuhada Alia Binti Seman, Akademi Menara Gading, Balok, Pahang, 26100, Malaysia.

Zainie Binti Ibrahim, Akademi Menara Gading, Balok, Pahang, 26100, Malaysia.

Nur Alia Afifah Binti Zakaria, Akademi Menara Gading, Balok, Pahang, 26100, Malaysia. both the first and second languages. Consequently, the researchers thus suggest that there is evidence of first language interference in ESL written texts.

$\mathrm{Ab}$ Manan and her colleagues [1] investigated the errors committed by twenty Malay pre-degree ESL learners in writing, which can be $\mathrm{s}$ credited to maternal tongue interference. The students were asked to write essays on a specified theme in both Malay and English. These essays were examined using an algorithm for conducting error analysis (EA). The results on L1 interference were identified as 'transfer of rules', 'redundancy reduction' and 'overgeneralization'. Transfer of rules indicates that in writing in L2, learners apply their knowledge with their mother language into their second language, especially when they do not have the writing fluency of the second language. Redundancy reduction happened when learners simplified or modified their second language sentence structures, while overgeneralization occurs when learners overuse the grammar rules due to their unfamiliarity with the structure. The finding of the study established that students' highest number of errors comes from 'redundancy reduction' category followed by 'transfer of rules' and 'overgeneralization'.

There is an ongoing dispute should the first language be or not be in an ESL classroom. However, it is made aware that some students cannot elude the fact they would use their first language to aid learning the language. This first language interference is what Ellis [10] pointed out as how learners' mother language overcomes the learning of their second language. He later explained that learners do so as they perceive their first language as transferable to their second language in their development of learning the language. This occasion is almost prevalent in Malaysian classroom, especially in secondary schools. Still, several recent local studies focus on syntactical error analysis [8][15][21] and strategies to improve writing [14][17][20][23][24] with only one study that focuses on first language interference in writing [1]. It is imperative, therefore, to identify types of secondary students' writing approach that is affected by the first language and the level of first language interference in their written essay. 


\section{LITERATURE REVIEW}

\section{A. First Language Interference}

A growing body of studies have been conducted about first language interference acquiring second language in which many researchers have proven through time [9][10][21][7][32][1].

A case study [1] investigated the interference of mother tongue in the second language among Chinese university students of the English Language and Communication (ELC) Department. 30 Chinese students, registered between January-May 2015, answered the questionnaire, interviewed and had their written paragraphs analyzed. The results of the study revealed that the most common mistakes are word selection, spelling, word form, articles, tenses, number, and agreement of subject and verb. The interview of 10 students from the May intake further reflected that participants were aware of the interference of their first language (L1) on their writing in English. During writing practice, they were comfortable in translation from their L1 to English. It can be inferred that L1 interference can be a conscious error which learners are aware of their lack of L2 writing skills.

Research by Sermsook, Liamnimitr, \& Pochakorn [32] on error analysis of written essays by 26 Thai EFL university students indicated that interlingual interference (L1 interference) as one of the reasons for errors in written texts. The participants were 26 second-year English major students; 2 males and 24 females aged 20-22 years old enrolled in Writing II course in a Thai university and had learned English for at least seven years. The analysis of the 104 written papers was categorized by sentential errors and word level errors, followed by a questionnaire which each participant outlines the reasons that led to their errors. This followed by interviews in groups or individually to probe the reasons for their errors. The result has revealed that most of the errors occur were at the syntactical and semantic levels.

Similarly, a study conducted on an analysis of interference effect on the gaining of English among Malays students in Malaysian secondary schools [21] discovered that the learners were still having difficulty in using accurate English grammar six years after of learning English. The 104 essays were collected from rural schools in three Malaysian states in. The essays were analysed using error analysis approach by Norrish [21] in which the stages were sample collection, describing errors, identifying errors, evaluating and explaining errors. The most common error occurred were at the syntactical level.

Darus \& Subramaniam [8] also supported the same result as they identified most Malay students faces difficulties in writing, especially in the English language. Their case study was on error analysis of 72 written essays of 72 Form four secondary students; 37 males and 35 females using the Markin software developed by Martin Holmes in 1996. The study has found that most errors occur were grammar, subject-verb-agreement and word choice.

Furthermore, a recent empirical study which examines the effect and interference of the first language on the second language acquisition, as well as the similarities and differences between among the two languages, was done by Derakhshan and Karimi [7]. They suggested that the interference of the native language on the second language is evident. Also, the study also reveals that there are also similarities and differences in the L1 and L2 such as in the structures of consonant clusters of the languages, learners' background knowledge, learners' second language proficiency, and the language structures. Moreover, the study also discovers that the more similar the structure of the first language is to the second language, the easier it is for the learner to learn it. Thus, it is clear that second language writing production can only be more accurate and coherent when both the L1 and the L2 of learners share almost the same features either in the syntactic or morphology of the languages' structures, learners' prior knowledge of the L2 and learners' proficiency in the language skills.

In short, it is true that the syntactic level in writing has always been one of the major errors outlined in many researchers [8][15][21]; however, the same level of error could also happen among native speakers such as in spelling [11] or sentence structure [7], to name a few. Therefore, by identifying specifically on which part of L1 interference that could affect target language writing performance will help both teachers to address the issue and for ESL learners to improve.

\section{B. Cross-linguistics Interference}

Cross-linguistics interference (CLI) happens when a language (L1) can affect the target language (L2) in a language learner [33]. This phenomenon can be seen in many aspects of language such as through orthography, phonology, semantics, morphology and syntax [28]. The concept can be divided into negative transfer; the differences of the first and second language, and the positive transfer; the similarities of the first and the second language [3]. Namely, positive language transfer can facilitate learners in obtaining language skills in their second language.

A study on the cross-linguistics influences in second language acquisition [2] explored the importance of L1 in the written production of L2 by analyzing the production errors made by 60 Spanish and 50 American students age 45 years old in relative to particular subsystems such as semantic and syntactic areas. The students were selected with the same age group, same course and university. The first group consisted of Spanish participants the and the second group was comprised of American participants. The first group's participants were beginners with low verbal and written skills in English, and they were not interested to learn English, but they had to take it as a compulsory course. The second group of students had a pre-intermediate level of Spanish and also motivated to learn Spanish. After sitting for a test to know their background, their feelings towards learning English and Spanish and the strategies used by them when studying a foreign language, the participants were asked to write a composition in English and Spanish. Next, they were requested to translate the same topic from their mother tongue to the secondary language. The last 
activity was composed of a vocabulary test in which the 'students had to guess the sense of the targeted words. The results indicated that language transfer is evident and plays an essential determining factor in the practice of second language learning.

By looking at the point of second language acquisition, the word transfer generally refers to how learners' first language influence in their target language. Bardovi-Harlig and Sprouse [4] in their paper on Negative Versus Positive Transfer published in the TESOL Encyclopedia of English Language Teaching state that both languages can either converge and diverge when it comes to achieving meanings and language productions. They refer positive transfer or facilitation as the influence of the first language that made the second language acquisition an easy task to perform. Conversely, they indicate negative transfer or interference as a kind of constraint learners must overcome as they produce errors in their language performance. Therefore, the negative transfer could have an inhibitory effect in mastering a language, while positive transfer could make learning a language less complicated and easy. Thus, the researchers conclude that knowing whether the second language is inhibited or facilitated will indicate if either of the transfers ever occurs.

Bennui [6] has conducted a study that analyses and describes features of L1 interference in paragraph writing by 28 third-year English-minor students who enrolled in the Basic Writing course in the 2006 semester 1 at Thaksin University. He identifies three levels on L1 interference as word level, sentence level and discourse level by considering the use of contrastive analysis, error analysis, interlanguage analysis, and contrastive rhetoric approaches. The result of the analysis suggested that the literal translation of Thai words into English represented features of L1 lexical interference in the essays. Moreover, structural borrowing such as word order, subject-verb agreement, and noun determiners from the Thai language indicated features of L1 syntactic interference. Moreover, the levels of language style and Thai cultural affiliation in written discourse presented features of L1 discourse interference. Hence, it is true that L1 interference can affect not only the word level and sentence level but also the discourse level of L2 writing production culturally.

A study by Ahmadian and his colleagues [2] on 36 Persian-speaking intermediate English learners on whether L1 use can significantly improve the quality of written productions in L2 and the aspects of writing that can be improved with L1 use reveals that positive language transfer can occur. Statistical comparisons of written argumentative paragraph from 12 groups of students; 4 males and 2 females per group, were randomly asked to use only English [L2 groups] in their collaborations as well as while performing the writing task, while the other half; 4 males and 2 females, were required to use their mother tongue, Farsi [L1 groups] was carried out. The results attested that L1 could positively improve the written score of the students in sentence cohesion and coherence, sentence development, grammar structure and sentence mechanics.
Similarly, research on L1 as a writing strategy for L2 [19] explored the degree of L1 use and various writing strategies in L2 writing to student proficiency levels and writing genres or writing tasks. Within the course of 14 weeks with nine Korean university students of three different proficiency levels performing six writing tasks in two genres, data analyses from the students think-aloud protocols and retrospective interviews suggested that L1 use in L2 writing can play an encouraging role for both the ideational and compensatory purposes, suggesting that the strategic use of L1 can contribute to improvement in L2 composition.

In a nutshell, cross-linguistic interference, positively seen as positive language transfer, can aid second language acquisition. Apart from being a definite indicator of language transfer, positive language transfer can improve students' writing skills.

\section{Identifying Types of Language Transfer}

Cross-linguistics interference has a number of definitions that run under the same theme such as the role of mother tongue and native language influence [25][16], language transfer [31][18][28], linguistics interference [30][12] and language mixing [31][18].

Weinrich [34] used the term interference, which mainly refers to any forms of language transfer. Therefore, L1 interference is related to language transfer. There are two ways to see language transfer; as a tool or a threshold in second language learning. Håkan Ringbom [12] stated that learners use their first language as a tool to compose, draft and to reduce the complexity of a second language writing task. For this reason, ESL learners, naturally, would use the writing strategy of their first language skill for their second language writing activity.

Odlin [28] outlines four common errors that fall under negative language transfer; underproduction, overproduction and production errors. Specifically, this paper will focus on production error that is relatable to writing skills. Substitution, loan translation/claque and under-differentiation happen in production error. Odlin describes substitution as the L1 learner replaces a word or structure of the native language within the target language. For example, my brother is riding a basic. Basikal in Malay is 'bicycle', but because the learner does not know the spelling for bicycle in English, he or she replaces it with a known spelling in the native language. Loan translation or claque is when the learner translates the L1 literally into L2 [5]. For instance, "tutup lampu" means "switch off the light" but the learner replaces the word 'tutup' into 'cover' which later written as "cover light". Lastly, under-differentiation happens when learners cannot differentiate between synonymous vocabularies, such as the word "borrow" and "lend". This errors mostly happen when learners use their dictionary skill to find the meaning of words or words with similar meanings or using Google Translate to translate their written text in the second language without editing. 
This paper will use themes under production error to identify the types of L1 interference in secondary school students writing approach.

\section{METHODOLOGY/MATERIALS}

\section{A. Research Design}

The design for this research is a mixed method with the combination of the quantitative and qualitative approach. The reason for this mixed method is to gain tangible data that is supported by the quantitative data to gain inner depth of the problem.

\section{B. Research Sample}

The populations are students aged 16 years old from a local secondary school in Pahang. The participants are 50 students selected from their recent English Language test; 23 with below average grade students, 13 with average grade students and 11 with above average grade students. The students' family background ranges from orphans and families with low socioeconomic background.

\section{Research Instrument and Procedure}

The instrument to measure the quantitative data is the Students L1 Tendency Questionnaire: The qualitative measurement, which is the students' essay samples. The Students L1 Tendency Questionnaire comprises of 6 questions with affective-scale responses.

The Students L1 Tendency Questionnaire survey on student participants was first carried out. As for the essay samples, the respondents were required to write an essay based on the given topic: "You are concerned over the implications and long-term health effects of the haze. Write an article to the local newspaper expressing your concern based on all the notes below".

Only 47 out of 50 students answered the survey, while all 50 students completed their essay samples.

\section{Data Analysis}

The data from the Students L1 Tendency Questionnaire is highlighted into themes; loan translation/claques, substitution and dictionary skill. The questionnaire is calculated based on percentage scores and in descriptive statistics. The independent items in the questionnaire are tabulated and presented in a graph. The student's essay samples are analyzed in the semantic level by measuring the number of direct translation sentences used by the students in the essay.

\section{RESUltS AND FINDINGS}

\section{A. Results of Descriptive Analysis}

The findings of this study are discussed in two sections, that is the Students L1 Tendency Questionnaire and the score range of the number of direct translation sentences used by the students in the essay.

\section{B. Students L1 Tendency Questionnaire}

Table 4.1.1: Overall frequency response of the Students L1 Tendency Questionnaire results

\begin{tabular}{|c|c|c|c|c|c|c|}
\hline Items & 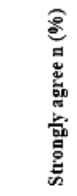 & 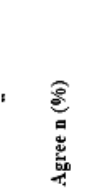 & 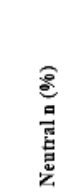 & 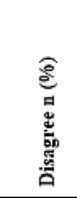 & 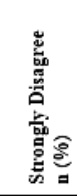 & 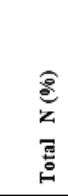 \\
\hline \multicolumn{7}{|l|}{ Loan translation / claques } \\
\hline $\begin{array}{l}\text { I often construct the sentence in } \mathrm{L} 1 \text { first } \\
\text { before translating it into } \mathrm{L} 2 \text { sentence }\end{array}$ & $\begin{array}{c}4 \\
(8.5)\end{array}$ & $\begin{array}{c}12 \\
(25.53)\end{array}$ & $\begin{array}{c}20 \\
(42.55)\end{array}$ & $\begin{array}{c}7 \\
(14.89)\end{array}$ & $\begin{array}{c}4 \\
(8.51)\end{array}$ & $\begin{array}{c}47 \\
(100.0)\end{array}$ \\
\hline $\begin{array}{l}\text { I tend to use direct translation from } \\
\text { L1 to L2 in my essay writing }\end{array}$ & $\begin{array}{c}4 \\
(8.5)\end{array}$ & $\begin{array}{c}13 \\
(27.66)\end{array}$ & $\begin{array}{c}19 \\
(40.43)\end{array}$ & $\begin{array}{c}4 \\
(8.51)\end{array}$ & $\begin{array}{c}7 \\
(14.89)\end{array}$ & $\begin{array}{c}47 \\
(100.0)\end{array}$ \\
\hline $\begin{array}{l}\text { I tend to apply L1 grammatical rules in } \\
\text { L2 structure }\end{array}$ & $\begin{array}{c}5 \\
(10.64)\end{array}$ & $\begin{array}{c}4 \\
(8.51)\end{array}$ & $\begin{array}{c}26 \\
(55.32)\end{array}$ & $\begin{array}{c}11 \\
(23.40)\end{array}$ & $\begin{array}{c}1 \\
(2.13)\end{array}$ & $\begin{array}{c}47 \\
(100.0)\end{array}$ \\
\hline Total & $\begin{array}{c}13 \\
(9.22)\end{array}$ & $\begin{array}{c}29 \\
(20.57)\end{array}$ & $\begin{array}{c}65 \\
(46.10)\end{array}$ & $\begin{array}{c}22 \\
(15.60)\end{array}$ & $\begin{array}{c}12 \\
(8.51)\end{array}$ & $\begin{array}{c}141 \\
(100.0)\end{array}$ \\
\hline \multicolumn{7}{|l|}{ Substitution } \\
\hline $\begin{array}{l}\text { I often substitute missing } L 2 \text { words } \\
\text { with } L 1 \text { words in my essay writing }\end{array}$ & $\left(\begin{array}{c}3 \\
(6.38)\end{array}\right.$ & $\begin{array}{c}14 \\
(29.79)\end{array}$ & $\begin{array}{c}6 \\
(12.77)\end{array}$ & $\begin{array}{c}11 \\
(23.40)\end{array}$ & $\begin{array}{c}13 \\
(27.66)\end{array}$ & $\begin{array}{c}47 \\
(100.0)\end{array}$ \\
\hline Total & $\begin{array}{c}3 \\
(6.38)\end{array}$ & $\begin{array}{c}14 \\
(29.79)\end{array}$ & $\begin{array}{c}6 \\
(12.77)\end{array}$ & $\begin{array}{c}11 \\
(23.40)\end{array}$ & $\begin{array}{c}13 \\
(27.66)\end{array}$ & $\begin{array}{c}47 \\
(100.0)\end{array}$ \\
\hline \multicolumn{7}{|l|}{ Under-differentiation } \\
\hline $\begin{array}{l}\text { I tend to use translation application to } \\
\text { translate my L1 sentences to } \mathrm{L} 2 \text {. }\end{array}$ & $\begin{array}{c}10 \\
(21.28)\end{array}$ & $14(29.79)$ & $\begin{array}{c}10 \\
(21.28)\end{array}$ & $\begin{array}{c}7 \\
(14.89)\end{array}$ & $\begin{array}{c}6 \\
(12.77)\end{array}$ & $\begin{array}{c}47 \\
(100.0)\end{array}$ \\
\hline $\begin{array}{l}\text { I use bilingual dictionary to look up for } \\
\text { equivalent words from } \mathrm{L} 1 \text { to } \mathrm{L} 2 \text {. }\end{array}$ & $\begin{array}{c}15 \\
(31.91)\end{array}$ & $15(31.91)$ & $\begin{array}{c}12 \\
(25.53)\end{array}$ & $\begin{array}{c}4 \\
(8.51)\end{array}$ & $\begin{array}{c}1 \\
(2.13)\end{array}$ & $\begin{array}{c}47 \\
(100.0)\end{array}$ \\
\hline otal & $\begin{array}{c}25 \\
(26.60)\end{array}$ & $\begin{array}{c}29 \\
(30.85)\end{array}$ & $\begin{array}{c}22 \\
(23.40)\end{array}$ & $\begin{array}{c}11 \\
(11.70)\end{array}$ & $\begin{array}{c}7 \\
(7.47)\end{array}$ & $\begin{array}{c}94 \\
(100.0)\end{array}$ \\
\hline
\end{tabular}

From Table 4.1.1, Item 6 has the most Strongly Agree response $(31.91 \%)$. However, the frequency of response is equal to Strongly response in the same item; which is also the highest in the Strongly response. Item 3 has the highest Neutral response $(55.32 \%)$ and the highest chosen response across the affective scale and questionnaire items. Item 3 and Item 4 shares the highest response in the Disagree scale (23.40\%), followed by Item 1 and Item 5 (14.89\%), and Item 2 and Item $6(8.51 \%)$. Item 4 has the highest Strongly Disagree response with $27.66 \%$ frequency, followed by Item $2(14.89 \%)$, Item $5(12.77 \%)$ and Item $1(8.51 \%)$. Item 3 and Item 6 shares the same response frequency of $2.13 \%$, which is the lowest in the effective scale and questionnaire items.

\section{1) Loan Translation / Claques}

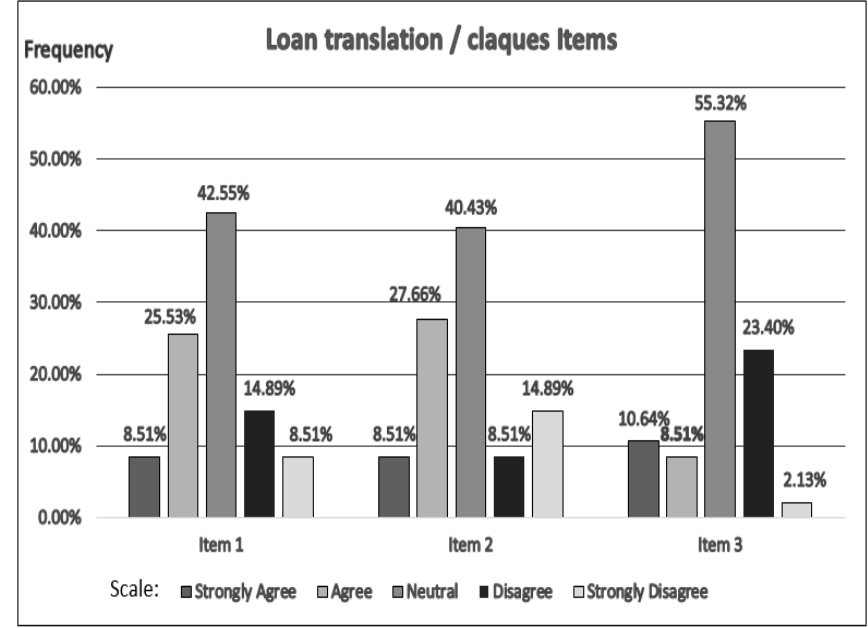

Figure 4.1.1 
From Figure 4.1.1, Item 1 has the most normal distribution of the frequency responses across the affective scale. This suggests that most students can relate the statements to themselves, and their answers are more definite. The graph in Item 2 is not much different from Item 1 with a slight change in the frequency of response from Disagree to Strongly Disagree scale. However, combining both frequency responses from Disagree and Strongly Disagree would produce the same result as Item 1. By adding Item 1, Item 2 and Item 3 frequency responses from Disagree to Strongly Disagree scales (Item 1: 23.40\%; Item 2: 23.40\%; Item 3: 25.53), the numbers for each item do not have any differences. On the other hand, by adding frequency responses Item 1 and Item 2 from the Strongly Agree to Agree scale, the result is almost the same (Item 1: 34.04; Item 2: 36.17\%). Instead of not following the same pattern as Item 1 and Item 2 on the same affective scale, Item 3 only has a cumulative of $19.15 \%$ responses. The reason could be that Item 3 has the highest frequency responses in Neutral scale than the other two items.

\section{2) Substitution}

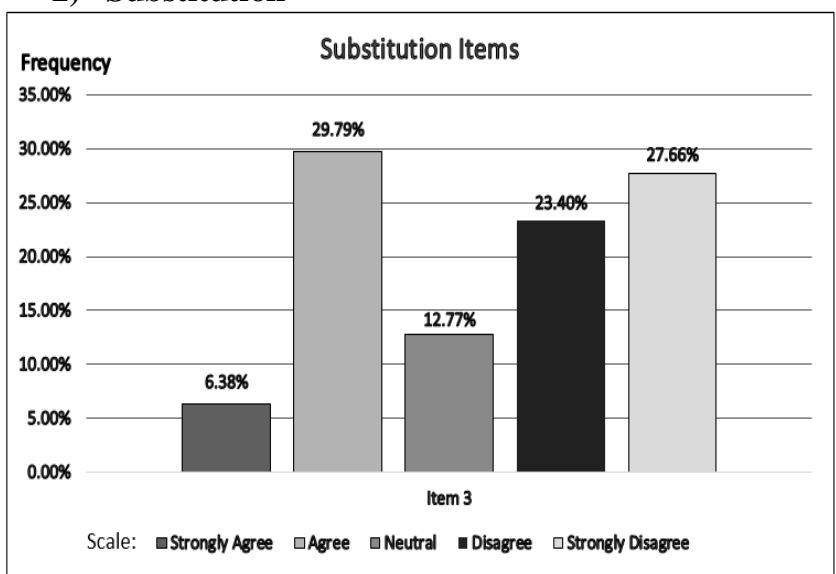

Figure 4.1.2

From Figure 4.1.2, the highest frequency responses start from Agree scale (29.79\%), followed by Strongly Disagree (27.66\%), Disagree $(23.40 \%)$ and ended with Strongly Agree (6.38\%). If the Neutral responses are isolated, it is portrayed that there are more responses from Disagree to Strongly Disagree (50.06\%) than Agree to Strongly Disagree (36.17\%).

\section{3) Under-differentiation}

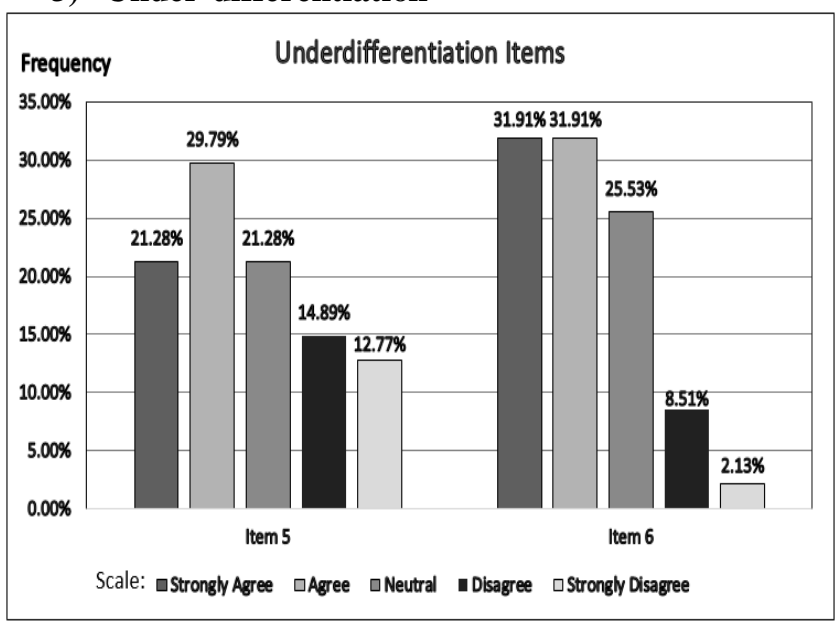

Figure 4.1.3
From Figure 4.1.3, the graph in Item 5 displays a normal distribution of frequency responses with the highest responses in Agree scale (29.79\%). From the current scale, the number of frequency responses drops as the graph move towards Strongly Disagree scale. The result shows that there are more positive responses to the statement in Item 5. Similarly, Item 6 also have the same outcome. Equal distribution from Strongly Agree to Agree scales, which indicates that most responses in favor of the statement Item 6.

\section{Essay Writing Analysis}

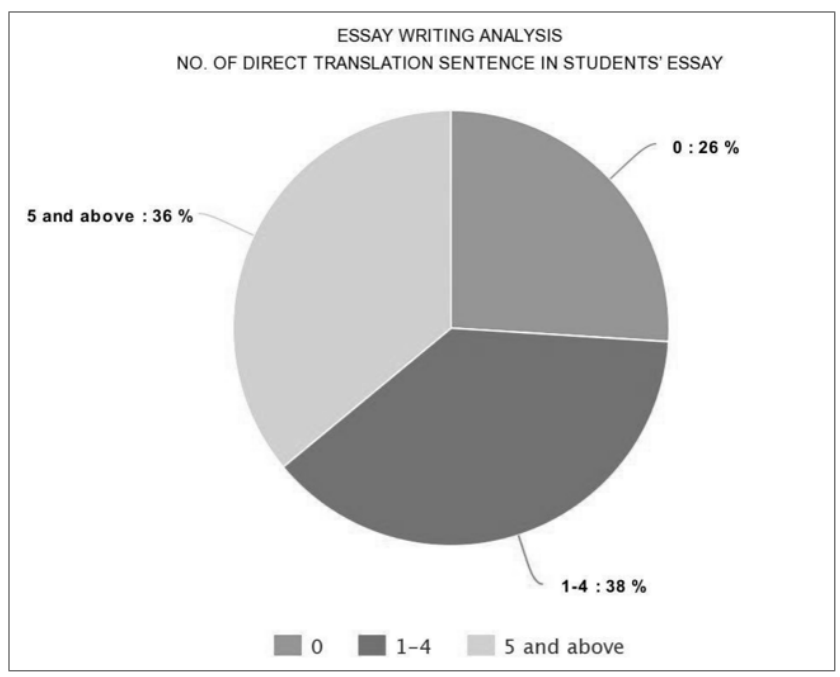

Figure 4.3.1

Based on the essay that had collected, it was found that most of the students have a direct translation sentence or word in their essay. The percentage is $38 \%$, which is the highest percentage among the categories divided. The data showed that at least the students had 1 until 4 direct translation sentences. Meanwhile, the second highest reading is $36 \%$, which the students did have 5 and more than that of direct translation sentences in their essay. And lastly, with the reading of $26 \%$, these students did not put any direct translation sentences in their essay. To conclude, students tend to put at least one direct translation sentence in their essay as they employ the L1 in aiding their L2 writing process.

\section{Discussion}

From Table 4.1.1., it is evident that most form four students in this study identify themselves as having under-differentiation in writing their essay. This is followed by loan translation/claques and substitution.

Referring to Figure 4.1.3 for Item 5 and Item, the graph seems to lean towards positive responses, thus reveal more students admit using translation app and dictionary in their written essay under the under-differentiation theme. Using a dictionary has been one of the language skills to produce accurate written products [3]. However, at times the misuse of dictionary can often lead to misappropriation of words in sentences. Therefore, when students use any form of dictionary/thesaurus; a book or an app, they will need a background knowledge of the L2 to know the appropriateness of each word

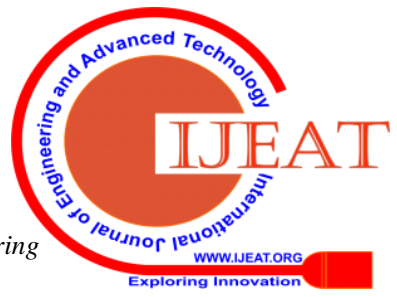


they try to find to fit in the context of their writing. Moreover, by referring back to the result under this theme, most participants can be considered an active user of the language when they use a dictionary to help them in writing. The reason is that participants have more instances of seeing new words such as synonyms and antonyms or to find meanings of the first language to the targeted language.

Loan translation/claques, which generally informed as direct translation, refers to speakers or writers applying knowledge from their first language to a second language. From Figure 4.1.1, most responses are positive about loan translation/claques to the statements in Item 1 and Item 2 in the loan translation/claque theme. The reason for such responses may be due to the fact both statement Item 1 and Item 2 are almost similar. Item 3 has the highest frequency of responses in Neutral scale, however, unlike Item 1 and Item 2 suggest loan translation/claques in general, Item 3 includes grammar as part of how participants do loan translation/claques. Some of the participants may not be sure that they commit grammar in their loan translation/claques. As a result, more frequency responses in Neutral scale for Item 3. The process of doing so maybe on purpose, however, students may not perceive themselves as capable in L1 or L2 syntactic skills; hence the highest Neutral scale.

In the substitution theme, half of the responses leaning towards disagreement that they commit substitution in their written essay. This suggests that the students do not know most of their words in the second language. It can be inferred that those who use substitutes in transferring their first language to their second language do not have access to dictionaries or any app concerning word translation or, they do not possess dictionary skill to use one. The result seems to correlate with the written analysis, which indicates there are almost half of the participants have L1 interference in their written essays.

From the analysis of written essay samples, shows that at least the students had 1 to 4 direct translation sentences in their L2 essay writing. The percentage of those students is $38 \%$, and it is the highest percentage. It is followed by the second highest percentage, which is $36 \%$ as the students made 5 and above of direct translation sentences to aid their L2 essay writing. Only $26 \%$ of the students did not have any pieces of evidence of L1 interference sentences in their essays. Overall, almost a quarter of form 4 students of Akademi Menara Gading seems to be able to produce at zero L1 interference in the sentences of their essays. This result suggests that instead of positive response in having L1 interference in their essay writing, some of the students may have managed to produce sound L2 written text.

\section{Conclusion}

The conclusion, L1 interference may affect the students writing product. However, on the other side of the coin, this interference may be positive, as indicated by Derakhshan and Karimi [7]. In addition, there are many ways students can do to improve their writing skills without relying on their L1 language transfer such as using social media to aid sentence construction [4] or using a computer program such as Provwrit [5].

Although this research combines quantitative and qualitative methods, the findings only focus on how students perceive as having L1 interference in writing essays and the analysis of L1 interference at the semantic level. Hence, another study in the future should also focus on delving more into the L1 interference among ESL learners written text. Apart from that, a bigger sample of the study could also complement more accurate results for generalization of the findings.

\section{REFERENCES}

1. Ab Manan, N. A., Zamari, Z. M., Pillay, I. A. S., Adnan, A. H. M., Yusof, J., \& Raslee, N. N. [2018]. Mother Tongue Interference in the Writing of English as a Second Language [ESL] Malay Learners. International Journal of Academic Research in Business and Social Sciences, 7[11], 1294-1301. https://doi.org/10.6007/ijarbss/v7-i11/3566

2. Ahmadian M, Pouromid S, Nickkhah M. Improving the Quality of Second Language Writing by First Language Use. Theory Pract Lang Stud. 2016;6[4]:767.

3. Almahammed, Y. S. O. [2016]. First Language Transfer In The Acquisition of English Prepositions By Jordanian EFL Learners. Universiti Sains Islam Malaysia.

4. Bardovi-Harlig K, Sprouse RA. Negative Versus Positive Transfer. TESOL Encycl English Lang Teach. 2017;1-6.

5. Backus A, Dorleijn M, Bullock BE, Toribio AJ. Loan translations versus code-switching. The Cambridge handbook of linguistic code-switching. 2009:75-94

6. Bennui P. A Study Of L1 Interference In The Writing of Thai EFL Students. Malaysian J ELT Res [Internet]. 2016;4[1]:31. Available from: http://journals.melta.org.my/index.php/majer/article/view/204

7. Crossley S, Duran ND, Kim Y, Lester T, Clark S. The action dynamics of native and non-native speakers of English in processing active and passive sentences. Linguist Approaches to Biling [Internet]. 2018;[February]. Available from: http://www.jbe-platform.com/content/journals/10.1075/lab.17028.cro

8. Darus, S., \& Subramaniam, K. [2009]. Error analysis of the written English essays of secondary school students in Malaysia: A case study. European Journal of Social Sciences, 8[3], 483-495. https://doi.org/10.1364/3D.2016.JT3A.38

7. Derakhshan, A., \& Karimi, E. [2015]. The Interference of First Language and Second Language Acquisition. Theory and Practice in Language Studies, 5[10], 2112-2117.

8. Dipolog-ubanan, G. F. [2016]. L1 Influence on Writing in L2 among UCSI Chinese Students: A Case Study. Pertanika Journal of Social Science and Humanities, 24[4], 1841-1853.

9. Dulay, H., Burt, M., \& Krashen, S. [1982]. Language two. New York: Oxford University Press.

10. Ellis, R. 1997, Second Language Acquisition, Oxford

University Press, Oxford.

11. Flor M, Futagi Y, Lopez M, Mulholland M. Patterns of misspellings in L2 and L1 English: a view from the ETS Spelling Corpus. Bergen Lang Linguist Stud. 2015;6[0].

12. Håkan Ringbom. The role of the first language in foreign language learning. Multilingual Matters Ltd; 1987.

13. Hanafi, A. [2014]. The second language Influence on foreign language learners' errors: The case of the French language for Algerian students learning English as a foreign language. European Scientific Journal, 10[10], 30-38.

14. Hashim, H., Md. Yunus, M., \& Ahmad, A. R. [2018]. Developing ESL Writing Skills: Understanding the Needs of the B40 Learners Introduction Who are the B40? In International Conference on Education, Islamic Studies and Social Sciences Research.

15. Hong, A. L., Abdul Rahim, H., Hua, T. K., \& Salehuddin, K. [2011]. Collocations in Malaysian English learners, writing: A corpus-based error analysis. 3L: The Southeast Asian Journal of English Language Studies, 17[[Special Issue]], 31-44.

16. Jarvis S, Odlin T. Morphological type, spatial reference, and language transfer. Studies in second language acquisition. 2000 Dec;22[4]:535-56. 
17. Kahairul Azam, F. K., Fadhil, F., \& Md. Yunus, M. [2019]. Enhancing ESL Learners ' Writing Skills via ProvWrit Enhancing ESL Learners ' Writing Skills via ProvWrit. International Journal of Academic Research in Bussiness \& Social Sciences, 9[1], 660-669. https://doi.org/10.6007/IJARBSS/v9-i1/5467

18. Kellerman E. Now you see it, now you don't. Language transfer in language learning. 1983;54[12]:112-34.

19. Kim Y, Yoon H. The use of L1 as a writing strategy in L2 writing tasks. GEMA Online J Lang Stud. 2014;14[3]:33-50.

20. Maarof, N., \& Murat, M. [2013]. Writing Strategies Used by ESL Upper Secondary School Students. International Education Studies, 6[4], 47-55. https://doi.org/10.5539/ies.v6n4p47

21. Maros, M., Hua, T. K., \& Salehuddin, K. [2007]. Interference in Learning English: Grammatical Errors in English Essay Writing Among Rural Malay Secondary School Students in Malaysia. Jurnal E-Bangi, 2[2], 1-15.

22. Mastan, M. E. B., Maarof, N., \& Embi, M. A. bin. [2017]. The effect of writing strategy instruction on ESL intermediate proficiency learners , writing performance. Journal of Education Research and Review, 5[September], 71-78. 9. Master PA. A cross-linguistic interlanguage analysis of the acquisition of the English article system [Doctoral dissertation, UCLA].

23. Md. Yunus, M., Hashim, H., Mohd Jaafar, N. F., Hazli, M. Z., Zairidan, N. I., \& Sahal, N. A. [2018]. ESL Learners' Acceptance Towards the Use of Technology in Enhancing Writing Skills. Journal of Advance Research in Dynamical \& Control Systems, 10[May], 1712-1718.

24. Md Yunus, M., \& Che Mat, S. S. [2014]. Writing Needs and Strategies of FELDA Primary ESL Pupils. Journal of Education and Human Development, 3[2], 1017-1035.

25. Mesthrie R, Dunne TT. Syntactic variation in language shift: The relative clause in South African Indian English. Language variation and change. 1990 Mar;2[1]:31-56.

26. Murat, M., \& Maarof, N. [2011]. Writing Strategies Used By Malaysian ESL Secondary School Students. In The 4th Biennial International Conference on the Teaching \& Learning of English in Asia: Forging Ahead [pp. 1-11].

27. Nunan, D. [1999]. Second Language Teaching and Learning. USA: Heinle \& Heinle Publishers.

28. Odlin T. Language transfer: Cross-linguistic influence in language learning. Cambridge University Press; 1989 Jun 30.

29. Phuket, P. R. N., \& Othman, N. B. [2015]. Understanding EFL Students ' Errors in Writing. Journal of Education and Practice, 6[32], 99-106.

30. Schachter J, Rutherford W. Discourse function and language transfer. Working Papers on Bilingualism Toronto. 1979[19]:1-1.

31. Selinker L. Interlanguage. IRAL-International Review of Applied Linguistics in Language Teaching. 1972;10[1-4]:209-32.

32. Sermsook K, Liamnimitr J, Pochakorn R. An Analysis of Errors in Written English Sentences : A Case Study of Thai EFL Students. English Lang Teach. 2017;10[3]:101-10.

33. Serratrice L. Cross-linguistic influence in bilingual development: When, Why, How. Linguist Approaches to Biling [Internet]. 2013;3[1]:3-25. Available from: http://www.jbe-platform.com/content/journals/10.1075/lab.3.1.01ser

34. Weinrich H. Semantics of the bold metaphor. German Quarterly Journal of Literary Science and Intellectual History. 1963 Aug. 1; 37 [3]: 325-44.

35. Zheng, B., Yim, S., \& Warschauer, M. [2017]. Social Media in the Writing Classroom and Beyond. The TESOL Encyclopedia of English Language Teaching, 1-5. https://doi.org/10.1002/9781118784235.eelt0555 